\title{
ПРОГНОЗИРОВАНИЕ ВЫСОКОПРОДУКТИВНЫХ УЧАСТКОВ ДРЕВНИХ ТРЕЩИННЫХ КАРБОНАТНЫХ РЕЗЕРВУАРОВ НА ОСНОВЕ КОМПЛЕКСНОГО АНАЛИЗА СКВАЖИННОЙ И СЕЙСМИЧЕСКОЙ ИНФОРМАЦИИ (НА ПРИМЕРЕ КУЮМБИНСКОГО МЕСТОРОЖДЕНИЯ ВОСТОчНОЙ СИБИРИ)
}

Харахинов В.В., Шленкин С.И., Зеренинов В.А., Кулиикина О.Н., Рудь О.В. (ООО "Спавнефть-НПЦ»)

Исследуемая территория расположена в пределах Камовского свода Байкитской антеклизы, осадочный чехол которой сложен верхнепротерозойскими и нижнепалеозойскими отложениями и разделяется на рифейский и венд-нижнепалеозойский структурные ярусы. Рифейские образования представлены мощными карбонатными и терригеннокарбонатными толщами. В строении терригеннокарбонатных комплексов реализована, главным образом, модель проградирующей во времени карбонатной платформы. На рифейских комплексах с размывом субгоризонтально залегают различные уровни вендских образований, перекрытые кембрийскими отложениями.

Нефтегазоносный резервуар представлен проницаемыми карбонатно-терригенными толщами рифея, характеризующимися весьма сложным строением. Региональной покрышкой служат вендские глинистые, сульфатные и карбонатные отложения. С целью выяснения особенностей строения трещинных карбонатных резервуаров были использованы специальные методический и технологический приемы для выявления высокопродуктивных участков, основанные на применении комплексной интерпретации сейсмической и скважинной информация. На основе изучения изменения динамических характеристик сейсмической среды и анализа седиментологических исследований в скважинах была построена схема распределения основных литологических типов карбонатных, терригенно-карбонатных пород. В свою очередь, по сейсмическим данным и информации о рассеивающих свойствах среды полученных по методике сейсмической локации бокового обзора (СЛБО) были выделены зоны дезинтеграции рифейских пород. В результате комплексирования всей имеющейся информация, в совокупности с результатами испытаний в скважинах, была полугена картина распределения высокопродуктивных участков, как по латерали, так и по вертикали. Как показывают результаты испытания скважин и распределения открытой трещиноватости коллекторов, выявленной на основе регистрации рассеянной компоненты волнового поля, нефтегазопродуктивность в пределах рассматриваемого участка имеет мозаичный, локальный характер, обусловленный изменчивостью фильтрационно-емкостныг свойств рифейского резервуара, зависит от степени его дезинтегрированности, определяемой в основном, наличием рифоподобных строматолитовых построек, характером разломной тектоники и субвертикальньх зон дезинтеграции, выявленных по сейсморазведке. Наиболее высоко-продуктивными оказались скважины, пробуренные в пределах дезинтегрированных фрагментов рифоподобных строматолитовых построек в различных сейсмокомплекcax.
Рифоподобные строматолитовые постройки, в силу их расположения над глубинными зонами дезинтеграции - основными каналами вертикальной митрации флюидов и значительной дезинтегрированности из-за высокого содержания кремнистого материала (восприимчивого к трещинообразованию), являются главными нефтегазоаккумулирующими элементами территории. В основном, эти сооружения образуют цепочки валообразных поднятий, занимающих достаточно большую территорию в пределах района работ. Скважины, пробуренные в их пределах, оказались высокопродуктивными. Рифоподобные постройки, приуроченные к разломным зонам северо-западного направления, оперяющим субширотные региональные сдвиги, окаймлены полосами повышенной трещиноватости, расширяощими поле продуктивности за пределы ареала распространения строматолитовых сооружений. В целом, деструктивная тектоника определяет характер внутреннего строения рифейского природного резервуара района работ и формирования зон аномальной трещиноватости резервуаров. Резервуары рифейских отложений, насыщенных УВ, отличаются сложностью строения. Продуктивная часть рифейского резервуара представлена в различной степени трещиноватыми и кавернозными доломитами, эффективный объём пустот которых обеспечен вертикальными и горизонтальными трещинами. Влияние деструктивной тектоники на формирование пустотного пространства рифейских резервуаров усилилось в период предвендской денудации. В разломных зонах в это время образовались карстовые полости, каверны и поры. Оконнательное формирование архитектуры пустотного пространства рифейских трещинных карбонатных резервуаров определено триасовыми и, особенно, кайнозойскими процессами флюидодинамической активизации в пределах юго-запада Сибирской платформы.

Таким образом, нефтегазогеологические, в первую очередь фильтрационно-емкостные, свойства рифейских природных резервуаров обусловлены особенностями их деформационной структуры и последующими изменениями в процессе геологического развития.

Прогнозирование высокопродуктивных участков древних трешинных карбонатных резервуаров потребовало применения не только современньх методик обработки и интерпретации сейсмических материалов, полученных в сложнейших сейсмогеологических условиях, но и внедрения новых специализированных технологий /1/ изучения трещиноватой среды (СЛБО, ФП-метода изучения рассеянной компоненты сейсмического поля). 